\title{
The red head and neck of Boer goats may be controlled by the recessive allele of the MC1R gene*
}

\author{
Zhao-Long WU ${ }^{\mathrm{a}, \mathrm{b}, \mathrm{c}, \mathrm{d}}$, Xiang-Long $\mathrm{LI}^{\mathrm{a}} \mathrm{b} * *$, Yan-Qiang LIU ${ }^{\mathrm{c}}$, Yuan-Fang \\ GoNG $^{\mathrm{b}}$, Zheng-Zhu LIU ${ }^{\mathrm{b}}$, Xiao-Juan WANG ${ }^{\mathrm{b}}$, Tian-Rong XIN ${ }^{\mathrm{e}}$, Qing JI ${ }^{\mathrm{c}}$
}

\author{
${ }^{a}$ College of Animal Science and Technology, Hebei Agricultural University, Baoding, Hebei Province, \\ 071001, P.R. China \\ ${ }^{\mathrm{b}}$ Department of Animal Science, Hebei Normal University of Science and Technology, Changli County, \\ 066600, Hebei Province, P.R. China \\ ${ }^{\mathrm{c}}$ College of Life Science, Nankai University, Tianjin, 300071, P.R. China \\ ${ }^{\mathrm{d}}$ School of Medicine, Jishou University, Jishou, 416000, Hunan Province, P.R. China \\ e School of Life Science, Nanchang University, Nanchang, 330047, Jiangxi Province, P.R. China
}

(Received 1 August 2004 - Accepted 24 February 2005)

\begin{abstract}
The Melanocortin-1-receptor (MC1R) gene is an important candidate gene for the coat color trait. In order to understand the molecular genetic basis of the red head and neck of Boer goats, a comparative analysis of $M C 1 R$ gene polymorphism in imported foreign breed Boer goats and another 26 goat populations including Boer goat offspring backcrossed to Tangshan Dairy goats $\left(F_{1}, F_{2}, F_{3}\right.$ and $\left.F_{4}\right), 18$ Chinese main indigenous goat breeds and four other imported foreign goat breeds (including a total of 319 individuals) were analyzed by PCR-RFLP. Two alleles of A and $\mathrm{B}$, and three genotypes of $\mathrm{AA}, \mathrm{AB}$ and $\mathrm{BB}$ were detected. The K226E (A676G) mutation of the $M C 1 R$ detected by sequencing distinguished the B allele from the A allele. The only AA genotype found in Boer goats was complete in accordance with their red head and neck. The Chi-square test suggested that the red head and neck of Boer goats may be controlled by the recessive A allele of the $M C 1 R$ gene. However, the K226E at the B allele may be a loss of function mutation associated with the whole white coat of goats.
\end{abstract}

Boer goat / red head and neck / MC1R gene / K226E mutation / white coat

Résumé - La tête et le cou rouge chez la chèvre Boer seraient contrôlés par un allèle récessif de $M C 1 R$. Le récepteur 1 de la mélanocortine $(M C 1 R)$ est un gène important pour le déterminisme génétique de la couleur du pelage. Pour comprendre la base moléculaire du caractère «tête et cou rouge » chez des chèvres Boer importées et chez 26 populations incluant des descendants améliorés par des croisements de cette chèvre avec celle de la variété laitière des Tangshan (F1, F2, F3, F4),

\footnotetext{
* This work was supported by National Natural Science Foundation of China (No. 30571326) and president foundation of Hebei agricultural university.

** Corresponding author: lixianglongen@yahoo.com
} 
18 races indigènes chinoises et quatre autres races étrangères importées, représentant un total de 319 individus, a été analysé par PCR-RFLP. Deux allèles A et B et trois génotypes AA, AB, BB, ont été détectés. La mutation $\mathrm{K} 226 \mathrm{E}$ (A676G) de MC1R détectée par séquençage a permis de distinguer les deux allèles A et B. Seuls les génotypes AA sont associés à «tête et cou rouge ». Le test de chi2 a montré que ce phénotype était contrôlé par l'allèle récessif $\mathrm{A}$ du gène $M C l R$ alors que l'allèle $\mathrm{B}$ (K226E) correspondrait à une perte de fonction et serait associé à un pelage complètement blanc.

chèvre Boer / tête et cou rouge / gène MC1R / mutation K226E / pelage blanc

\section{INTRODUCTION}

It is generally acknowledged that the head and neck color of Boer goats is brown or red except for a white band in the region from the middle of the forehead to the extremity of the nose, and their body color is white. Li et al. [5] confirmed that the red head and neck of Boer goats are controlled by one recessive gene on an autosome that shows a simple Mendelian inheritance. It is regrettable that neither the identity of the recessive gene nor the molecular genetic basis of its phenotype have been reported so far.

$M C 1 R$ plays a critical role in the control of melanin synthesis [1]. It is a seven transmembrane, G-protein-coupled receptor that is activated by the melanocytestimulating hormone (MSH), leading to an increase in black/brown eumelanin production in melanosomes that are then transferred to the surrounding hair. In many mammals, a gain of function of $M C l R$ variants is associated with an increase in the production of eumelanin, while loss of function variants is associated with an increase in red/yellow phaeomelanin production [2-4, 6, 9-12]. A loss of the function variant is also associated with the white coat color of bears [8]. Moreover, $M C 1 R$ variants have been found to be overrepresented in humans with red hair [13]. However, the $M C 1 R$ variants in goats have not been reported except for part of its sequence in GeneBank (AY292287), in which G259A was found to be the Ear I restriction site. In order to investigate the association of the candidate MCIR gene with the red head and neck of Boer goats, a comparative analysis of $M C 1 R$ polymorphism was carried out in Boer goats and 26 other goat populations based on PCRRFLP, with the intention of learning more on the genetic basis of the recessive color trait of the head and neck of Boer goats and providing experimental evidence on Boer goat pure propagation and their potentially improved cross to Chinese indigenous goat breeds.

\section{MATERIALS AND METHODS}

\subsection{Samples and DNA extraction}

A total of 319 goat samples were included in this investigation. The samples represented the imported breed Boer goats and their offspring backcrossed to Tangshan Dairy goats, 18 Chinese main indigenous goat breeds and four other imported breeds (Angora goat, Toggenburg goat, $\mathrm{Nu}$ bian goat, Saanen goat), together with coat color recorded for each goat population. DNA extraction was conducted by the phenol extraction method.

\subsection{Primer design, PCR amplification and sequencing}

Since the complete sequence of the goat $M C 1 R$ gene has not been sequenced, three primer pairs used to amplify the different fragments of the goat $M C 1 R$ gene, E1, E2 and E3, were designed according to the homologous region between the complete ovibos moschatus sequence (GenBank Accession No. Y13958), part 
of the goat sequence (AY292287) and the complete sheep sequence (GenBank Y13965). The primers were as follows: E1, forward 5' gtggaccgctacatctccat and reverse 5' ttgaagatgcagccacagg; E2, forward 5' gctgctgggttccettaact and reverse 5 ' gggcgtagaagatggagatg and E3, forward 5 ' tgcctcgttggcttcttc and reverse 5'gcacctcttggagcgtctt. The E1 primer was used to amplify the $416 \mathrm{bp}$ fragment (bases from 418 to 833) of the MC1R gene (AY292287) in order to study the relationship between SNP and color variation. In order to find new SNP, the E2 and E3 primers were used to amplify the $422 \mathrm{bp}$ fragment (bases from 27 to 448) and the 367bp fragment (bases from 571 to 937) of the MC1R gene respectively from 10 goats representing five breeds with different coat colors (Boer goat, Chengdu Brown goat, Nanjiang Brown goat, Shannan White goat, Leizhou goat); each breed was comprised of two goats. PCR products amplified by E2 and E3 were sequenced by Bioasia biological and technology Co. Ltd. (Beijing, China), and PCR products of E1 were used to perform PCR-RFLP.

PCR was carried out in a PTC- $100^{\mathrm{TM}}$ Programmable Thermal Controller (MJResearch, Inc, U.S.A.) with a total volume of $30 \mu \mathrm{L}$ reaction containing $4 \mu \mathrm{L}$ (75 ng. $\mu \mathrm{L}^{-1}$ ) of goat genomic DNA, $3 \mu \mathrm{L}$ of $10 \times \mathrm{PCR}$ standard reaction buffer, $2.4 \mu \mathrm{L}$ dNTP $\left(2.5 \mathrm{pmol} \cdot \mathrm{L}^{-1}\right.$ of each deoxynucleotide), $1.2 \mu \mathrm{L}\left(10 \mathrm{pmol} \cdot \mathrm{L}^{-1}\right)$ of each forward and reverse primer, $0.3 \mu \mathrm{L}$ (5 U. $\mu \mathrm{L}^{-1}$ ) of Taq DNA Polymerase (TaKaRa Biotechnology Co., Ltd., Dalian, China) and $17.9 \mu \mathrm{L}$ of distilled water. After pre-denaturation for $3 \mathrm{~min}$ at $94{ }^{\circ} \mathrm{C}$, the PCR profile consisted of a denaturation step at $94{ }^{\circ} \mathrm{C}$ for $45 \mathrm{~s}$, an annealing step at $64{ }^{\circ} \mathrm{C}$ for $45 \mathrm{~s}$, and an elongation step at $72{ }^{\circ} \mathrm{C}$ for $1 \mathrm{~min}$ for a total of 34 cycles, followed by a final extension of $10 \mathrm{~min}$ at $72{ }^{\circ} \mathrm{C}$. The PCR products were run on $1.5 \%$ agarose gel including $10 \mathrm{mg} \cdot \mathrm{mL}^{-1}$ of ethidium bromide, and were visualized and photographed with a gel automatic photographer under UV light.

\subsection{PCR-RFLP of MC1R and genotype determination}

The PCR-RFLP was performed using Ear I (Sino-American Biotechnology Company, Beijing, China) recognizing GAAGAG and cutting at position 671 according to the alignment between Y13958 and the sequenced results. The digestion solution with a total volume of $10 \mu \mathrm{L}$ containing $5 \mu \mathrm{L}$ of PCR products, $1 \mu \mathrm{L}$ $\left(10 \mathrm{U} \cdot \mu \mathrm{L}^{-1}\right)$ of Ear I, $3 \mu \mathrm{L}$ of distilled water and $1.0 \mu \mathrm{L}$ of $10 \times$ buffer, was incubated at $37{ }^{\circ} \mathrm{C}$ for $2 \mathrm{~h}$ in the PTC$100^{\mathrm{TM}}$ Programmable Thermal Controller. Genotyping was completed by running digested products on $2 \%$ agarose gel including $10 \mathrm{mg} \cdot \mathrm{mL}^{-1}$ of ethidium bromide. Homozygote AA was defined when base A existed at position 676 forming GAAGAG being recognized by Ear I; homozygote $\mathrm{BB}$ was defined when base $\mathrm{G}$ existed at this position forming GGAGAG not being recognized by Ear I, and heterozygote $\mathrm{AB}$ was defined when $A$ and $G$ existed at the same position of the homologous chromosome.

\subsection{Statistical test of inheritance of head and neck color of Boer goats}

A chi-square test of SPSS software (version 11.5) was performed to test the inheritance of head and neck color of $F_{2}$ offspring of Boer goats backcrossed to $F_{1}$ and of $F_{3}$ offspring of Boer goats backcrossed to $F_{2}$ goats with white heads and necks.

\subsection{Alignment of $M C 1 R$ protein sequences in mammals}

In order to analyze the lysine $(\mathrm{K})$ conservation of $M C 1 R$ protein in mammals, 
Table I. MC1R genotype and coat color in Boer goats and their offspring.

\begin{tabular}{lccccccc}
\hline \multirow{2}{*}{ Groups } & \multicolumn{3}{c}{ Number of samples } & & \multicolumn{2}{c}{ Head and neck color } & \multirow{2}{*}{ Body color } \\
\cline { 2 - 3 } & Total & AA & AB & & AA & AB & \\
\hline Boer goats & 41 & 41 & - & & red & - & white \\
$\mathrm{F}_{1}$ & 7 & - & 7 & & - & white & white \\
$\mathrm{F}_{2}$ & 53 & 26 & 27 & & red & white & white \\
$\mathrm{F}_{3}$ & 56 & 44 & 12 & & red & white & white \\
$\mathrm{F}_{4}$ & 6 & 6 & - & & red & - & white \\
\hline
\end{tabular}

Note: $F_{3}$ were the offspring of Boer goats to $F_{2}$ (including red, white head and neck individuals).

eight complete sequences (317aa) were obtained from goats (SWISSPROT Accession No. P56444), ovibos moschatus (SWISSPROT P56447), sheep (SWISSPROT O19037), cows (SWISSPROT P47798), red deer (SWISSPROT P56445), horses (NCBI AAK70924), cats (NCBI NM_001009324) and humans (SWISSPROT Q01726), respectively, aligned by MEGA software (Version 2.1).

\section{RESULTS}

\subsection{Polymorphism of MC1R nucleotide sequences of goats}

Six $M C 1 R$ nucleotide sequences were successfully obtained, including four sequences amplified by the E2 primer and two by the E3 primer. According to the goat MC1R protein sequence (SWISSPROT P56444) and the sequenced results, 5 SNP were found in five of six sequences; the remaining sequence amplified by the E2 primer was not found to have an amino acid variant. Amongst 5 SNP, the R9L (25CTG27, at the first extracellular domain of $M C 1 R$ ) variant was detected in one Boer goat and one Shannan White goat; G49W (145TGG147, at the first transmembrane region) was found in one Chengdu Brown goat, and F250V (748GTC750) and G234D (700GAC702) variants were identified in the other Boer goat, which were at the sixth transmembrane region and the third cytoplasmic domain, respectively. Meanwhile, this Boer goat was identified as an AA homozygote at the 676 site, whereas the other Shannan White goat with white coat color was identified as a GG homozygote at the same site, and the $676 \mathrm{~A} \rightarrow \mathrm{G}$ transition resulted in a $226 \mathrm{~K} \rightarrow \mathrm{E}$ variant (at the third cytoplasmic domain) in this goat.

\subsection{MC1R genotype and coat color in Boer goats and their offspring}

Table I gives the $M C 1 R$ genotype and coat color in Boer goats and their backcrossed offspring to Tangshan Dairy goats. Genotype AA, AB and BB could be identified from the electrophoresis of restriction fragments (Fig. 1). Only the AA genotype was found in 41 Boer goats that had red heads and necks and only the $\mathrm{AB}$ genotype was found in $F_{1}$ animals with white heads and necks that were the offspring of Boer goats and Tangshan Dairy goats with white head and neck color. There were two types of head and neck color observed in $F_{2}$ offspring of Boer goats backcrossed to $F_{1}$. One type was the red head and neck observed in 26 homozygous AA goats, and the other type was characterized as the white head and neck in 27 AB heterozygotes. The red and white heads and necks were also observed in $F_{3}$ of Boer goats backcrossed to $F_{2}$, and 12 of 44 red head 


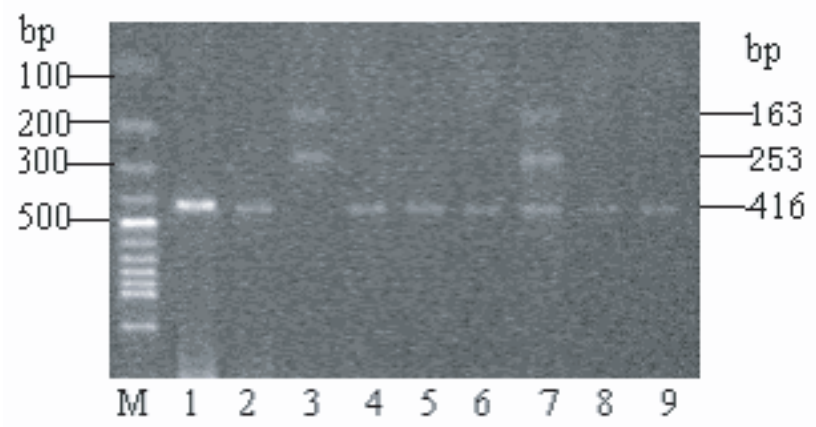

Figure 1. RFLP of $M C 1 R$ gene digested by Ear I. Note: $M$ refers to DNA Marker $(\lambda \mathrm{DNA} /$ Ecor $1+$ Hind III); lane 1 illustrates PCR production of $M C 1 R$; lane 3 illustrates the AA genotype with bands of $253 \mathrm{bp}$ and 163bp; lane 7 illustrates the $\mathrm{AB}$ genotype with bands of 416bp, 253bp and 163bp, respectively; the remaining lanes illustrate the BB genotype with only one band of 416bp.
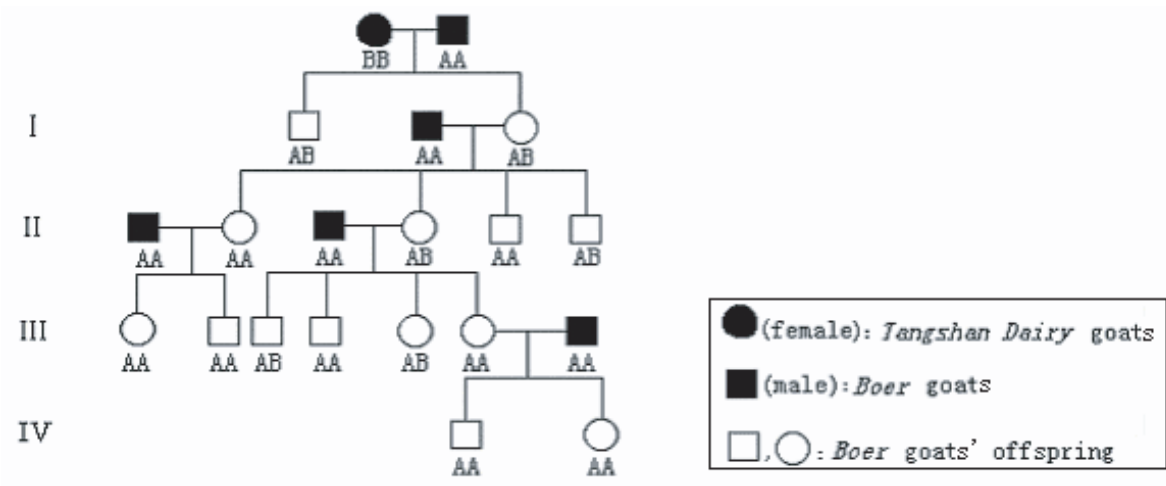

Figure 2. The family of Boer goats and their upgrading offspring to Tangshan Dairy goats.

and neck goats in $F_{3}$ were the offspring of Boer goats backcrossed to the white head and neck goats in $F_{2}$, and the other 32 individuals were the offspring of Boer goats backcrossed to the red head and neck of goats in $F_{2}$. Since the BB genotype was not detected in Boer goats and their offspring, it was deduced that the Tangshan Dairy goats should have the BB genotype in light of family lineage (Fig. 2). A chisquare test of inheritance of head and neck color for Boer goats is shown in Table II.

\subsection{MC1R genotype and coat color in Chinese and imported breeds}

Table III gives the MC1R genotype and coat color in 18 Chinese main indige- nous goat breeds and four imported foreign goat breeds. Eighty-nine individuals from 11 breeds with white coat, except for one Chuangdong White goat and one Duan goat that were AA homozygote and the other two Duan goats that were AB heterozygote, all presented the BB genotype. Nubian goats with red coat presented the same AA genotype as the Boer goats with red heads and necks. Within the group of imported breeds (Angora goat, Toggenburg goat, Nubian goat and Sannen goat), the frequencies of the $\mathrm{A}$ and $\mathrm{B}$ allele were $35.3 \%$ and $64.7 \%$, of AA respectively. The frequencies of the $\mathrm{AB}$ and $\mathrm{BB}$ genotypes were $35.3 \%, 0 \%$ and $64.7 \%$, respectively; the corresponding values within the group of Chinese indigenous goat breeds were $7.6 \%$ and $92.4 \%$, and $4.3 \%, 6.5 \%$ and 
Table II. Chi-square test of inheritance of head and neck color of Boer goats.

\begin{tabular}{|c|c|c|c|c|c|c|}
\hline \multirow{2}{*}{ Offspring } & \multirow{2}{*}{ Head and neck color } & \multicolumn{2}{|c|}{ Number of female (Q) } & \multicolumn{2}{|c|}{ Number of male $\left(\sigma^{\prime \prime}\right)$} & \multirow{2}{*}{ Chi-square test } \\
\hline & & Obs. & Exp. & Obs. & Exp. & \\
\hline \multirow{3}{*}{$\mathrm{F}_{2}$} & red & 17 & 15 & 9 & 11.5 & \multirow{3}{*}{ 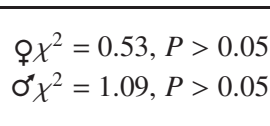 } \\
\hline & white & 13 & 15 & 14 & 11.5 & \\
\hline & total & 30 & 30 & 23 & 23 & \\
\hline \multirow{3}{*}{$\mathrm{F}_{3}$} & red & 4 & 5 & 8 & 7 & \multirow{3}{*}{$\begin{array}{l}\stackrel{\chi^{2}}{ }=0.40, P>0.05 \\
\sigma^{\prime \prime} \chi^{2}=0.29, P>0.05\end{array}$} \\
\hline & white & 6 & 5 & 6 & 7 & \\
\hline & toatl & 10 & 10 & 14 & 14 & \\
\hline
\end{tabular}

Note: $\mathrm{F}_{3}$ were the offspring of Boer goats crossed to the white head and neck individuals in $F_{2}$.

Table III. MC1R genotype and coat color in Chinese main indigenous goat breeds and imported goat breeds.

\begin{tabular}{lccccc}
\hline \multirow{2}{*}{ Breeds } & \multicolumn{4}{c}{ Number of samples } & \multirow{2}{*}{ Coat color } \\
\cline { 2 - 5 } & Total & AA & AB & BB & \\
\hline Angora goat & 8 & - & - & 8 & white \\
Saanen goat & 2 & - & - & 2 & white \\
Nubian goat & 3 & 3 & - & - & red \\
Toggenburg goat & 4 & 3 & - & 1 & brown \\
Liaoning Cashmere goat & 10 & - & - & 10 & white \\
Jining Grey goat & 7 & - & - & 7 & grey \\
Chengde Polled goat & 10 & - & - & 10 & black \\
Taihang Mountain goat & 3 & - & - & 3 & black \\
Jianchang Black goat & 7 & - & - & 7 & black \\
Inner Mongolia Cashmere goat & 8 & - & - & 8 & white \\
Chengdu Brown goat & 6 & - & 2 & 4 & brown-yellow \\
Tibetan goat & 8 & - & - & 8 & black \\
Nanjiang Brown goat & 5 & - & - & 5 & tan \\
Shannan White goat & 6 & - & - & 6 & white \\
Chuandong White goat & 10 & 1 & - & 9 & white \\
Guizhou White goat & 13 & - & - & 13 & white \\
Yichang White goat & 10 & - & - & 10 & white \\
Longlin goat & 6 & - & - & 6 & white \\
Matou goat & 9 & - & - & 9 & white \\
Duan goat & 7 & 1 & 2 & 4 & white \\
Guizhou Black goat & 3 & - & 1 & 2 & black \\
Leizhou goat & 11 & 4 & 4 & 3 & black \\
\hline
\end{tabular}

$89.2 \%$, respectively. The results showed that both Chinese breeds and imported breeds demonstrate a comparatively high $\mathrm{B}$ allele and $\mathrm{BB}$ genotype frequency; the A allele, $\mathrm{AA}$ and $\mathrm{AB}$ genotype frequency for them was lower.

\subsection{Conservative lysine of mammal $M C 1 R$ protein sequences}

The alignment of the $M C 1 R$ protein sequences of eight mammals was shown in Figure 3 . The 226 site, at the cytoplasmic 


\begin{tabular}{|c|c|c|c|c|c|c|}
\hline & 10 & 20 & 30 & 40 & 50 & 60 \\
\hline human & MAVOGSORRL & LGBLNBTPTA & IPQLGLAANO & TGARCLEVBI & SDGLFL BLGL & VBLVBNALVV \\
\hline \multicolumn{2}{|c|}{ red deer.P.I..... } & ...... & TFP.T. .P.R & $\ldots$ PQ....A. & P....... & $\ldots \ldots v \ldots$ \\
\hline ovibos & . PAL..... & .......P. & TLP.T. . P.R & $\ldots P Q \ldots \ldots$ & PN...... & $\ldots \ldots v \ldots$ \\
\hline cow &. PAL..... & ....... & TLPFT. . P.R & $\ldots P Q \ldots \ldots$ & P...... & $\ldots . . . \mathrm{v} \ldots$ \\
\hline goat & . PAI . P... & $\ldots \ldots$ c. & TLP.T. . P.R & $\ldots$ PQ ..... & P....... & $\ldots . . .6 \ldots$ \\
\hline sheep & P.L...... & $\ldots \ldots$ C.P. & TLP.T. .P.R & $\ldots$ PQ. . . . & P....... & $\ldots \ldots v \ldots$ \\
\hline cat & . S...P... & $\ldots \ldots$ gP. & A.R..... & .P....I.V & P....G... & $\ldots v \ldots v \ldots$ \\
\hline \multirow[t]{2}{*}{ horse } & .PL..P... & $\ldots \ldots \ldots$ LP. & T.Y...TT. & . BPR . . . . & P...... & $\ldots \ldots v \ldots$ \\
\hline & $61 \quad 70$ & 80 & 90 & 100 & 110 & 120 \\
\hline human & ATIAKNRWLH & SPMYCPICCI & ALSDLLVBGB & NVLETAVILL & LEAGALVARA & AVLOOLDNVI \\
\hline red deer & C.A. . . . Q & $\ldots \times \ldots \ldots$ & M...... & $\ldots \ldots \ldots \ldots$ & ....A... & $\ldots v \ldots \ldots$ \\
\hline ovibos & A. . . . . . & ........ & M..... v. & ........ & ...V.ATQ. & $\ldots v \ldots . .$. \\
\hline eow & A....... & $\ldots . . \ldots$ &.$v \ldots \ldots$ v. & ........ & .... V.ATQ. & $\ldots v \ldots . .$. \\
\hline goat & A. . . . . & $\ldots x \ldots$ & M. . . . v. & $\ldots \ldots$ M. & ...V.AT. & $\ldots v \ldots . .$. \\
\hline sheep & A. $\ldots \ldots$ & $\ldots \times \ldots$ & M..... v. & $\ldots \ldots \ldots$ & ....А. . & $\ldots v \ldots \ldots$ \\
\hline cat & A. . . . . & $\ldots$. & $v \ldots \ldots v$ & S......... & .....AG. & .V.R..DI. \\
\hline \multirow[t]{2}{*}{ horse } & TA....... & $\ldots$. . . . & . v........ & ...M.IL. & .... V.ATQ. & g........ \\
\hline & $121 \quad 130$ & 140 & 150 & 160 & 170 & 180 \\
\hline human & DVITCS\$MLS & \$LCPLGAIAV & DRYISIFYAL & RYHSIVTLPR & ARRAVAAIWV & AsVVPSTLFI \\
\hline red deer & F..II.G..V. & $\ldots \ldots \ldots$ & $\ldots \ldots \ldots$ & $\ldots v \ldots$ & W.II..... & .ILT.I. . \\
\hline ovibos & .LI....V. & $\ldots \ldots \ldots$ & $\ldots \ldots \ldots$ & $\ldots v \ldots$ & .W.II.... & ..ILT.V.s. \\
\hline eow & .II.G.V. & $\ldots \ldots \ldots$ & $\ldots \ldots \ldots$ & $\ldots$. & .N.II.... & . ILT.I. . \\
\hline goat & . II . . . V. & $\ldots \ldots \ldots$ & $\ldots \ldots \ldots$ & $\ldots$ v. . . . & N.II..... & .ILT.V.s. \\
\hline sheep & . II. ...V. & $\ldots \ldots \ldots$ & $\ldots \ldots \ldots$ & $\ldots v, \ldots$ & , $\mathbb{E} . \operatorname{II} \ldots$. & .ILT.V. \\
\hline cat & .LV.GA,V. & $\ldots \ldots \ldots$ & & $\ldots \ldots \ldots$ & W..Ig.... & $\ldots$ Is..... \\
\hline \multirow[t]{2}{*}{ horse } & WIIG. V. & $\ldots \ldots$ s... & $\ldots \ldots \ldots$ & . . . . Mar. . & vw. .IV.... & v. . Is.... \\
\hline & $181 \quad 190$ & 200 & 210 & 220 & 230 & 240 \\
\hline human & AYXDHVAVLL & CLVUFPLAML & VLMAVLYVHM & IARACOHAQG & IARLHKRORP & VHOGPGLKGA \\
\hline \multicolumn{2}{|c|}{ red deerT. N.TV... } & ..G.I... & A. . . . . . & $\ldots \ldots \ldots$ R. & $\ldots . .$. & I. . . . . \\
\hline ovibos & T..N.TV... & ...G.... & A....... & $\ldots$ R. R R. & $\ldots$ Q $\ldots$. & $I \ldots \ldots \ldots$ \\
\hline eow & T..N.KVI.. & ...GI.I... & A. . . . . & $\ldots \ldots R$ & $\ldots Q . \ldots$ & I....... \\
\hline goat & T..N.TV... & ..G.I... & A. $\ldots \ldots \ldots$ & $\ldots \ldots R$ R. & $\ldots . . .$. & $I \ldots \ldots \ldots$ \\
\hline sheep & T..N.TV... & ..G.I... & A. $\ldots \ldots$. & $\ldots \ldots$ R. & $\ldots . \ldots$ & $I \ldots \ldots \ldots$ \\
\hline gat & $\ldots \ldots$ T... & ...ง..... & $\ldots \ldots \ldots$ & $\ldots \ldots R$ R. & $\ldots \ldots \ldots$ & $\ldots$. L . . . . \\
\hline \multirow[t]{2}{*}{ horse } & $\ldots$ N.T... & ... . . . & $\ldots \ldots \ldots$ & $\ldots \ldots \ldots R$ & $\ldots \ldots \ldots$ н. & I........ \\
\hline & $241 \quad 250$ & 260 & 270 & 280 & 290 & 300 \\
\hline human & VTLTILLGIP & PLCWGPFFLH & LTLIVLCPEH & PTCGCIPKNP & NLPLALIICN & AIIDPLIXAP \\
\hline \multicolumn{2}{|c|}{ red deerA...... V. } & $\ldots \ldots \ldots$ & s....... & $\ldots \ldots \ldots$ & $\ldots \ldots \ldots$ & $\ldots v \ldots \ldots$ \\
\hline ovibos & A....... & $\ldots \ldots \ldots$ & $.8 \ldots \ldots$. & $\ldots \ldots \ldots$ & $\ldots \ldots \ldots$ & $\ldots v \ldots . .$. \\
\hline eow & A....... v. & $\ldots \ldots \ldots$ & $.8 \ldots \ldots$. & $\ldots \ldots \ldots$ & $\ldots \ldots \ldots$ & $\ldots v \ldots . .$. \\
\hline goat & A...... & $\ldots \ldots \ldots$ & $.8 \ldots \ldots$ & $\ldots \ldots \ldots$ & $\ldots \ldots \ldots$ & $\ldots v \ldots \ldots$ \\
\hline sheep & A. . . . . V. & $\ldots \ldots \ldots$ & . $. \ldots .$. & $\ldots \ldots \ldots$ & $\ldots \ldots \ldots$ & $\ldots v \ldots \ldots$ \\
\hline cat & A. . . . . . & $\ldots \ldots \ldots$ & S.M....R. & .I...V... & $\ldots$ T.... & s.v..... \\
\hline horse & $\begin{array}{l}\text { A....... V. } \\
301 \\
310\end{array}$ & ${ }_{317} \ldots \ldots$ & .S.II...Q. & $\ldots \ldots v \ldots$ & K...T. . I. S & $\ldots v \ldots \ldots$ \\
\hline human & HBQELRRTLK & EVLTCSW & & & & \\
\hline \multicolumn{2}{|c|}{ red deerk.....k. . Q } & $\ldots$. . . & & & & \\
\hline ovibos & R....R. . Q & $\ldots Q \ldots$ & & & & \\
\hline eow & R.....R..Q & $\ldots Q \ldots$ & & & & \\
\hline goat & R....R. . Q & $\ldots Q \ldots$ & & & & \\
\hline sheep & R. . . K. . Q & $\ldots 0 .$. & & & & \\
\hline cat & R....R. . Q & ...... & & & & \\
\hline horse & R....R. . Q & $\ldots$ L... & & & & \\
\hline
\end{tabular}

Figure 3. Alignment of $M C 1 R$ protein sequences of eight mammals. 
domain of $M C 1 R$, is a conservative lysine $(\mathrm{K})$ among the eight mammals. Thus the K226E variant found in one Shannan White goat sequence was confirmed to be a missense mutation, since this mutation just located at the Ear I recognition site allows distinguishing the $\mathrm{B}$ allele from the A allele. In addition, the eight mammals were observed with the conservative $\mathrm{K}$ at sites 65,238 and 278 , in which $65 \mathrm{~K}$ and $238 \mathrm{~K}$ were at the cytoplasmic domain of $M C 1 R$ and only $278 \mathrm{~K}$ was at the extracellular domain. The conservative $307 \mathrm{~K}$ observed in seven mammals was also located at the cytoplasmic domain, but the nonconservative mutation of $\mathrm{K} \rightarrow \mathrm{R}$ at the same site has been observed in humans.

\section{DISCUSSION}

\subsection{The red head and neck of Boer goats may be controlled by the MC1R gene}

The AA genotype was perfectly in accordance with the red head and neck of Boer goats, suggesting that the A allele of the MCIR gene was strongly associated with such a phenotype. If the recessive A allele controls the red head and neck of the Boer goat, and the dominant $B$ allele controls the white head and neck of the Tangshan Dairy goat, then the $F_{1}$ of Boer goats crossed to Tangshan Dairy goats should be $A B$ heterozygote; the red head and neck individuals in both $F_{3}$ and $F_{4}$ should be AA homozygote; this deduction was well proven by the genotype identification described above. The intercross between Boer goats and $F_{1}$, and between Boer goats and white head and neck individuals in $F_{2}$ equals to a backcross, thus, theoretically, the ratio of red head and neck individuals to white head and neck individuals both in $F_{2}$ and $F_{3}$ from such an intercross should be 1:1. A chisquare test showed that the difference be- tween the number of red head and neck individuals and of white head and neck individuals both in females and males of $F_{2}$ was not significant, thus the ratio between them was in accordance with the expectation value of $1: 1$, as in $F_{3}$. The statistical results suggest that the red head and neck of Boer goats may be mainly controlled by the recessive A allele of the MC1R gene, supporting the opinion that this color trait belongs to autosome inheritance and could be explained by Mendelian law [5]. Here, it must be pointed out that the conservative $226 \mathrm{~K}$ of the A allele may be indispensable for forming the red head and neck of Boer goats, and does not exclude the possibility that there be variants at other sites of the A allele, for example, R9L, F250V and G234D found in Boer goats. But this deduction should be supported by sequencing based on more samples and correlated statistical tests.

\subsection{Speculation on the genetic basis of the Boer goats' white body}

The head and neck color of Boer goats is red, whereas their body color is white. Two distinctly different coat colors distributed in the same breed implies that the white body of Boer goats may not be controlled by the MCIR gene but probably by other gene (s) as follows: firstly, some gene inhibits melanocyte cell differentiation or migration from the neural crest to the body; secondly, some gene makes melanocytes lose its ability to deposit melanosomes in body hair; thirdly, a few genes directly inhibit the enzymes and related proteins from being produced, which are responsible for melanogenesis; fourthly, some genes with mutants inhibit the interaction of $\alpha$-melanocyte stimulating hormone with the target melanocytes, and possibly all of these genes interact to give the final Boer goats' white body. 


\subsection{Association of the K226E mutation with the whole white coat of goats}

Since nearly all individuals were identified as the BB genotype among 11 whole white coat breeds, the $\mathrm{B}$ allele is potentially associated with such a color phenotype. As Figure 3 shows, there are four conservative Ks at the cytoplasmic domain in goat $M C 1 R$ protein sequences; consequently, the conservative $226 \mathrm{~K}$ at the third cytoplasmic domain may play an important role in determining the function of MCIR. The non-conservative K226E mutation at the $\mathrm{B}$ allele is a replacement of a positive charged $\mathrm{K}$ with a negative charged $\mathrm{E}$, and this kind of $\mathrm{K} \rightarrow \mathrm{E}$ mutation may be a loss of function mutation, resulting in the loss of melanin production and leading to the formation of the whole white coat of goats. Conversely, the kind of $\mathrm{E} \rightarrow \mathrm{K}$ mutation seems to be a gain of function mutation, which is strongly associated with melanism of birds [7] and mice [9], the chicken's black coat is also possible due to this kind of mutation [2]. It is noteworthy that the $\mathrm{K} \rightarrow \mathrm{E}$ mutation found in this investigation was not at the second transmembrane region, which is apparently a key function part in $M C 1 R$, since many mutations associated with coat color variation in chickens [2], mice [9], cattle [4], and horses [6] are located at the second transmembrane; but at the third and the seventh transmembrane region, even at the cytoplasmic domains, for example, at the third and the fourth cytoplasmic domain, there are also some mutations related to the coat color difference in animals $[3,8,10$, 11], implying that the coat color variation in different animals is possibly determined by mutations at different $M C 1 R$ regions. Some other goat breeds, even if they had markedly various coat color (for example, the black of Chengde Polled goats, grey of Jining Grey goats and tan of Nanjiang Brown goats) also presented the BB genotype; such a phenomenon where genotype does not match the phenotype, on the one hand revealed the K226E mutation was not an important mutation associated with coat color variance among these breeds; on the other hand, that it may be due to different genetic background among them.

The following could be concluded: the red head and neck of Boer goats may be controlled by the recessive A allele of the MC1R gene, and the K226E mutation of $M C I R$ was potentially associated with the whole white coat of goats. The B allele variant of $M C 1 R$ overwhelmingly distributed in the Chinese goat population and imported foreign goat population contributes to the understanding of the evolution of the goat $M C 1 R$ gene.

\section{ACKNOWLEDGEMENTS}

We express our gratitude to Liu Yang, Liu Hui-Juan, Li Yue-Hui, Hao Qing, Yin ShengHui, Zheng Zhan-Chong, Song Xing-Chao, Zhang Hao, Xu Yu-Fu at Hebei Normal University of Science and Technology for great help in the preparation of the experiment. This work was supported by the National Natural Science Foundation of China (No. 30571326) and president foundation of Hebei agricultural university.

\section{REFERENCES}

[1] Jackson I.J., Homologous pigmentation mutations in human, mouse and other model organisms, Hum. Mol. Genet. 6 (1997) 1613 1624.

[2] Kerje S., Lind J., Schutz K., Jensen P., Andersson L., Melanocortin 1-receptor (MC1R) mutations are associated with plumage colour in chicken, Anim. Genet. 34 (2003) 241-248.

[3] Kijas J.M., Wales R., Tornsten A., Chardon P., Moller M., Andersson L., Melanocortin receptor 1 (MC1R) mutation and coat color in pigs, Genet. 150 (1998) 1177-1185.

[4] Klungland H., Vage D.I., Gomez-Raya L., Adalsteinsson S., Lien S., The role of 
melanocyte stimulating hormone (MSH) receptor in bovine coat color determination, Mamm. Genome 6 (1995) 636-639.

[5] Li Xiang-long, Gong Yuan-fang., Liu Zhengzhu, Han Xiu-li, Inheritance of head and neck colour and black hoof of Boer Goat, Hereditas 24 (2002) 659-662.

[6] Marklund L., Moller K.J., Sandberg K., Andersson L., A missense mutation in the gene for melanocyte stimulating hormone receptor $(\mathrm{MC} 1 \mathrm{R})$ is associated with the chestnut coat colour in horses, Mamm. Genome 7 (1996) 895-899.

[7] Mundy N.I., Kelly J., Theron E., Hawkins K., Evolutionary genetics of the melanocortin-1 receptor in vertebrates, Ann. N. Y. Acad. Sci. 994 (2003) 307-312.

[8] Ritland K., Newton C., Marshall H.D., Inheritance and population structure of the white-phased "Kermode" black bear, Curr. Biol. 11 (2001) 1468-1472.

[9] Robbins L.S., Nadeau J.H., Johnson K.R., Kelly M.A., Roselli-Rehfuss L.,
Baack E., Mountjoy K.G., Cone R.D., Pigmentation phenotypes of variant extension locus alleles result from point mutations that alter MSH receptor function, Cell 72 (1993) 827-834.

[10] Schmutz S.M., Berryere T.G., Goldfinch A.D., TYRP1 and MC1R genotypes and their effects on coat color in dogs, Mamm. Genome 13 (2002) 380-387.

[11] Väge D.I., Lu D., Klungland H., Lien S., Adalsteinsson S., Cone R.D., A non-epistatic interaction of Agouti and Extension in the fox, Vulpes vulpes, Nat. Genet. 15 (1997) 311-315.

[12] Väge D.I., Klungland H., Lu D., Cone R.D., Molecular and pharmacological characterization of dominant black coat colour in sheep, Mamm. Genome 10 (1999) 39-43.

[13] Valverde P., Healy E., Jackson I.J., Rees J.L., Thody A.J., Variants of the melanocytestimulating hormone receptor gene are associated with red hair and fair skin in humans, Nat. Genet. 11 (1995) 328-330. 